\title{
CMV on surfaces in homes with young children: results of PCR and viral culture testing
}

\author{
Minal M. Amin ${ }^{1}$, Jennifer D. Stowell ${ }^{2}$, William Hendley ${ }^{1}$, Philip Garcia ${ }^{1}$, D. Scott Schmid ${ }^{1}$, Michael J. Cannon ${ }^{1}$ \\ and Sheila C. Dollard ${ }^{1 *}$ (D)
}

\begin{abstract}
Background: Caring for young children is a known risk factor for cytomegalovirus (CMV) infection mainly through exposure to their saliva and urine. In a previous study, 36 CMV-seropositive children 2 mo. to 4 years old were categorized as CMV shedders $(n=23)$ or non-shedders $(n=13)$ based on detection of CMV DNA in their saliva and urine. The current study evaluated the presence of CMV on surfaces in homes of the children.

Methods: Study staff made 4 visits to homes of the 36 enrolled children over 100 days. Saliva was collected by swabbing the mouth and urine was collected on filter paper inserted into diapers. In addition, five surface specimens were collected: three in contact with children's saliva (spoon, child's cheek, washcloth) and two in contact with children's urine (diaper changing table, mother's hand). Samples were tested by PCR and viral culture to quantify the presence of CMV DNA and viable virus.

Results: A total of 654 surface samples from 36 homes were tested; 136 were CMV DNA positive, 122 of which (90\%) were in homes of the children shedding CMV $(p<0.001)$. Saliva-associated samples were more often CMV positive with higher viral loads than urine-associated samples. The higher the CMV viral load of the child in the home, the more home surfaces that were PCR positive $(p=0.01)$ and viral culture positive $(p=0.05)$.

Conclusions: The main source for CMV on surfaces in homes was saliva from the child in the home. Higher CMV viral loads shed by children correlated with more viable virus on surfaces which could potentially contribute to viral transmission.
\end{abstract}

Keywords: Cytomegalovirus, Viral shedding, Infectious virus, Transmission

\section{Background}

Cytomegalovirus (CMV) infection is the most common cause of congenital viral infection in developed countries. Primary infection and reinfection of adults occurs at higher rates among those in contact with young children in the home, daycare centers and schools [1-3]. Children appear to be an important source for CMV infection in all of these environments $[4,5]$. Many studies have tracked CMV shedding in young children showing that virus is shed in the saliva and urine of half or more of young seropositive children, and that rates of shedding peak at

\footnotetext{
* Correspondence: sgd5@cdc.gov

${ }^{1}$ Centers for Disease Control and Prevention (CDC), 1600 Clifton Road NE, Atlanta, GA 30329, USA

Full list of author information is available at the end of the article
}

1-2 years of age [5-8]. For women of reproductive age, contact with young children poses the greatest risk for transmission [9]. Parents with children shedding CMV have 10 times the seroconversion rate of parents whose children are not shedding CMV [10]. Although direct contact with child saliva and urine is a well-known transmission risk, very few studies have tested surfaces that contact children's fluids for their potential to harbor CMV and contribute to transmission.

In this study, we tested for the presence of CMV by quantitative PCR and viral culture on samples taken from surfaces in homes where young CMV-seropositive children lived to better understand potential routes of CMV transmission beyond direct contact with the saliva and urine of shedding children. 


\section{Methods}

\section{Study population and specimen collection}

In a previous study we enrolled 36 healthy, CMVseropositive children 2 mo. to 4 years old (mean age 17 months) that were still in diapers from regional daycare centers and pediatrician's offices in the metropolitan Atlanta area. None of the children had chronic medical conditions or had been diagnosed with congenital CMV infection [11]. Saliva was collected by using a sterile oral swab as previously described [11]. Urine collection was done by providing disposable diapers to parents that had strips of filter paper inserted in the front panel (Whatman 903 paper used in the U.S. newborn screening (NBS) program). Previous studies have reported using filter paper to collect urine and test for CMV [12, 13]. Urine-soaked inserts were removed with tweezers by the parents, air-dried 4 to $12 \mathrm{~h}$ on a clean nonporous surface, placed in Ziploc bags and stored in the refrigerator until the next staff visit, usually within $24 \mathrm{~h}$. Ultraviolet light causes urine on the filter paper to fluoresce to verify its presence. One $6 \mathrm{~mm}$ punch was taken and processed for DNA extraction using the same method used to test blood on filter paper for CMV [14].

Surface specimens were collected at 4 times by study staff at the same visits where saliva and urine were collected from children. At each visit, 5 surface specimens were collected using sterile cotton-tipped swabs (Fisher Scientific, Pittsburg, PA) pre-moistened with phosphate buffered saline (PBS): (1) Spoon; spoon shortly after removal from child's mouth, (2) Cheek; child's cheek area where there was visible moisture, (3) Washcloth; washcloth shortly after the mother used it to wipe the child's mouth, (4) Hands; the palm of the mother's hand immediately after a diaper change, (5) Changing area; changing table immediately after a diaper change. Swabs were immediately immersed in $1 \mathrm{ml}$ viral transport media (VTM, Fisher Scientific, Pittsburg, PA) in $15 \mathrm{ml}$ tubes, placed on ice and transported to the CDC laboratory for processing, the same day in most cases.

\section{CMV detection by polymerase chain reaction (PCR) and viral culture}

Swabs in VTM were removed to a syringe and centrifuged $10 \mathrm{~min}$ at $2000 \mathrm{rpm}$ to extract liquid which was mixed back with the VTM. For PCR testing, $100 \mu \mathrm{l}$ was removed and mixed with $100 \mu \mathrm{l}$ of Quick Extract buffer (EpiCenter, Madison, WI), incubated $1 \mathrm{~h}$ at $56{ }^{\circ} \mathrm{C}$, then $100{ }^{\circ} \mathrm{C}$ for $3 \mathrm{~min}$, then cooled on ice. The extract was used for Taqman-based PCR targeting the CMV gB gene [15] with commercially standardized human CMV DNA quantitated with digital PCR by Advanced Biotechnologies, Inc. (Eldersburg, MD) included on every PCR plate. NB: The international CMV PCR standard provided by the
World Health Organization from a manufacturer in England has been logistically difficult for U.S. residents to purchase. For analysis low viral load was defined as $<10^{4}$ copies/ml, medium viral load as $10^{4}-10^{6}$ copies $/ \mathrm{ml}$, and high viral load as $>10^{6}$ copies $/ \mathrm{ml}$.

For viral culture, the remaining VTM (about $0.9 \mathrm{ml}$ ) was added to a T-25 tissue culture flask containing human lung fibroblast cells (ATCC, Manassas, VA, USA) from which media had been removed. Following $1 \mathrm{~h}$ adsorption, $5 \mathrm{ml}$ of fresh culture medium with antibiotics was added to the flask. Cultures were observed for cytopathic effect twice per week for 3 weeks. Urine samples were dried on filter paper and thus not usable for culture.

\section{Statistical analysis}

Associations were examined using SAS version 9.3 (Cary, NC). We calculated $P$-values for proportions by using the chi-square or Fisher's exact tests as appropriate. When comparing viral loads or antibody titers, we used the Cochran-Mantel-Haenszel test and the Wilcoxon ranksum test.

\section{Results}

\section{Specimens collected and presence of CMV by PCR}

A total of 913 specimens were collected over 4 visits from 36 children in 35 households; 259 specimens were from children and 654 from surfaces. Figure 1 shows PCR results for all samples collected at all visits for the children who were shedding CMV at enrollment, and Fig. 2 shows the same for children who were not shedding CMV at enrollment. The enrollment visit was prior to day 0 and is not shown in Figs. 1 and 2. CMV DNA was detected in 59\% (502/846) of saliva specimens and $20 \%(167 / 844)$ of urine specimens [16]. Among surface specimens, 136/654 (21\%) were CMV DNA positive, $90 \%$ of which $(123 / 136)$ were collected from homes of the shedding children $(p<0.001)$ and $10 \%$ from the homes of non-shedding children which was mainly from one home where the child began shedding CMV after enrollment.

\section{CMV viral load}

Specimens were CMV PCR positive at a rate of $12-56 \%$ depending on the type of specimen (Table 1). Generally, saliva and saliva-associated surfaces samples resulted positive at higher frequency and with higher viral loads than urine and urine-associated surface samples., with statistically significant differences listed in Table 1 and as followssaliva compared to every other source; Spoon and cheek compared to urine, hands and changing area. Mean viral loads were significantly different for the following pairs: Saliva compared to cheek, washcloth, urine, hands, and changing area. Spoon, cheek, washcloth and 


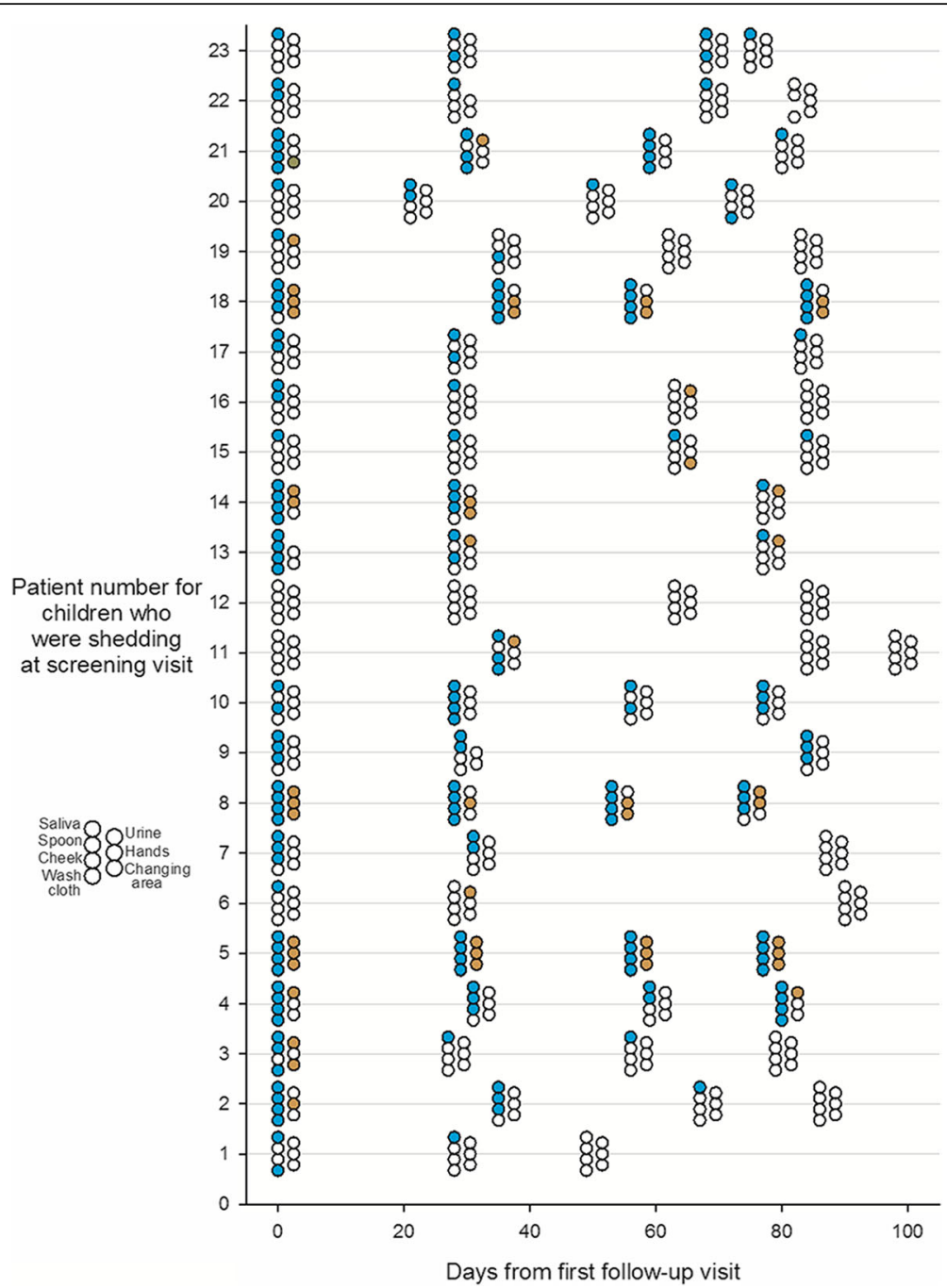

Fig. 1 CMV PCR results on specimens collected in homes of children shedding CMV. Various specimens were collected at four follow-up visits to homes over 100 days. Children living in the homes were shedding CMV when tested at the screening visit which was prior to the first follow-up and is not shown on the graph. Colored circles signify a positive result, open circles a negative result. Blue color is for saliva and its contact surfaces, yellow is for urine and its contact surfaces. At each visit, up to seven specimens were collected, as shown to the left of the chart

urine compared to hands and changing area. Median viral loads were significantly different for the following pairs: Saliva, spoon, cheek, washcloth and urine compared to hands and changing area. Figure 3 displays the full range and median viral load (horizontal line) for each specimen type. Median viral loads were similar for saliva and urine; however, saliva-associated surfaces (spoon, cheek, wash cloth) had more of the high viral load specimens compared to urine-associated surfaces (hands, changing area). Figure 4 shows the correlation between increasing CMV viral loads in children's saliva and increasing portion of surfaces in the home that were CMV-positive $(p=0.01)$ as evidence that the shedding child in the home was the source of CMV in the home. The same three viral load categories shown in Table 2 were used for analysis in Fig. $4\left(<10^{4}, 10^{4}-10^{6},>10^{6}\right)$.

\section{Presence of CMV by viral culture}

Valid viral culture results were available for 64\% (398/ 626) of specimens processed for culture; $36 \%$ failed for technical reasons including poor quality cell sheets $(20 \%)$, or heavy bacterial contamination (16\%) despite the use of antibiotics in culture media. Culture results by specimen type are displayed in Table 1 . Most (62/64 $=97 \%$ ) of the culture-positive specimens were also CMV PCR positive and thus Table 1 lists culture results only for PCR-positive specimens. Spoons from the mouths of children were more often viral culture positive $(50 \%)$ than other surfaces tested $(7-25 \%)(p=0.05)$. The higher viral load specimens were saliva and saliva-associated surfaces and were more often positive by viral culture than lower viral load specimens associated with urine. Urine was not amenable to viral culture testing because 


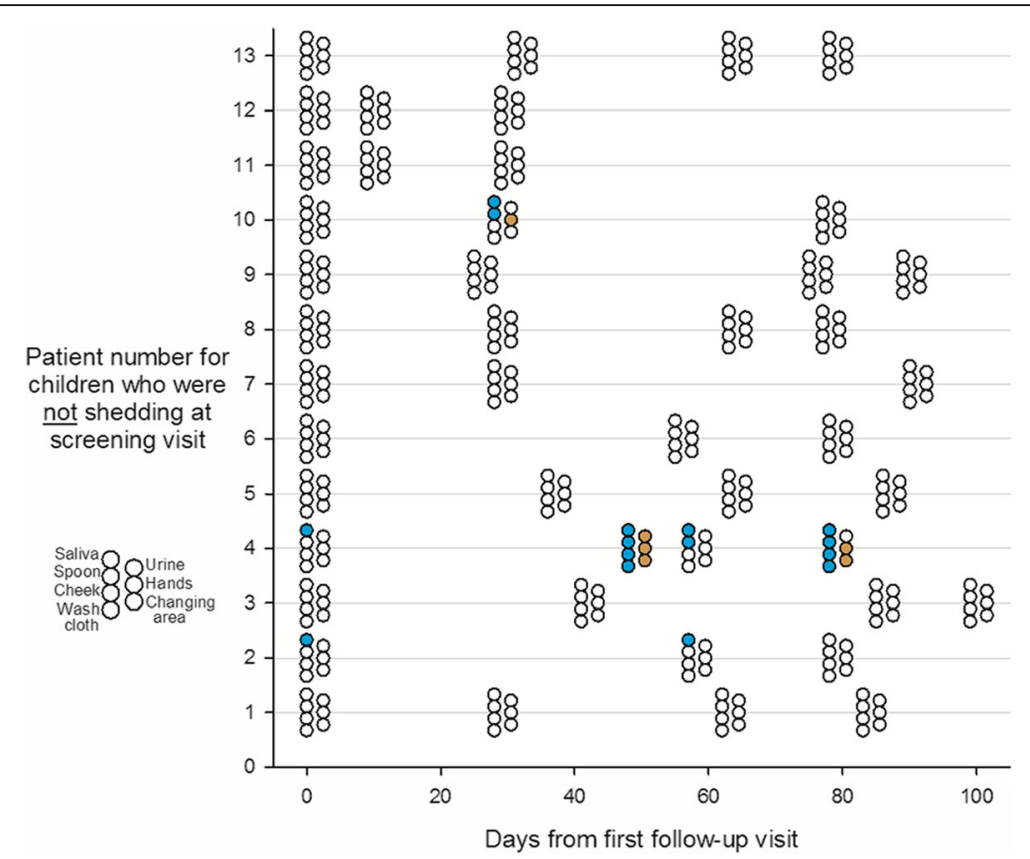

Fig. 2 CMV PCR results on specimens collected in homes of children not shedding CMV. Various specimens were collected at four follow-up visits to homes over 100 days. Children living in the homes were not shedding CMV when tested at the screening visit which was prior to the first follow-up and is not shown on the graph. Colored circles signify a positive result, open circles a negative result. Blue color is for saliva and its contact surfaces, yellow is for urine and its contact surfaces. At each visit, up to seven specimens were collected, as shown to the left of the chart

it was dried on filter paper. High PCR viral load was strongly associated with positive viral culture (Table 2; test for linear trend for percent positive, $<0.001$ ).

\section{Discussion}

Our study evaluated CMV on various home surfaces exposed to saliva and urine of young CMV-seropositive children to better understand potential routes of transmission. The same children were enrolled in a related study that took weekly measurements of their saliva and urine over 100 days to measure CMV shedding [11, 16]. Results of the current study indicate that children in the home were the main source of CMV on home surfaces, and that the child's saliva was more a source of virus than the child's urine. This would be expected since urine is generally contained by diapers whereas saliva is not contained by a barrier. Multiple lines of evidence support our findings: $90 \%$ of the CMV DNA-positive specimens were found in homes where the shedding children lived and $10 \%$ in the homes where non-shedding children lived (mainly in one home where the child began shedding after enrollment), and rates of CMV positivity of home surfaces increased with higher CMV viral loads of the child in the home. Other

Table 1 Results of CMV detection by PCR and cell culture from different sample types (saliva- and urine-associated)

\begin{tabular}{llllllll}
\hline Source & $\begin{array}{l}\text { No. positive/ } \\
\text { total tested }\end{array}$ & $\begin{array}{l}95 \% \text { confidence i } \\
\text { nterval for proportion }\end{array}$ & $\begin{array}{l}\text { Mean viral load } \\
(\text { copies/mL) }\end{array}$ & $\begin{array}{l}\text { Standard } \\
\text { deviation } \\
(\text { copies/mL) }\end{array}$ & $\begin{array}{l}\text { Median viral load } \\
(\text { copies/mL) }\end{array}$ & $\begin{array}{l}\text { Interquartile range, } \\
\text { Q1-Q3 (copies/mL) }\end{array}$ & $\begin{array}{l}\text { No. positive/ } \\
\text { total cultures }\end{array}$ \\
\hline Saliva & $73 / 131(56 \%)$ & $47-64 \%$ & $1.15 \times 10^{7}$ & $3.01 \times 10^{7}$ & $2.08 \times 10^{5}$ & $1.07 \times 10^{4}-3.42 \times 10^{6}$ & $44 / 54(81 \%)$ \\
Spoon & $39 / 131(30 \%)$ & $22-38 \%$ & $5.86 \times 10^{6}$ & $2.45 \times 10^{7}$ & $5.47 \times 10^{4}$ & $1.55 \times 10^{4}-4.26 \times 10^{5}$ & $10 / 20(50 \%)$ \\
Cheek & $38 / 130(29 \%)$ & $22-39 \%$ & $1.22 \times 10^{6}$ & $4.76 \times 10^{6}$ & $5.25 \times 10^{4}$ & $1.20 \times 10^{4}-3.80 \times 10^{5}$ & $4 / 16(25 \%)$ \\
Wash cloth & $25 / 131(19 \%)$ & $13-27 \%$ & $2.53 \times 10^{5}$ & $6.10 \times 10^{5}$ & $7.83 \times 10^{4}$ & $1.39 \times 10^{4}-1.27 \times 10^{5}$ & $3 / 12(25 \%)$ \\
Urine & $20 / 128(16 \%)$ & $10-23 \%$ & $1.05 \times 10^{5}$ & $1.10 \times 10^{5}$ & $5.46 \times 10^{4}$ & $2.57 \times 10^{4}-1.43 \times 10^{5}$ & Not done \\
Hands & $18 / 131(14 \%)$ & $8-21 \%$ & $4.05 \times 10^{4}$ & $3.65 \times 10^{5}$ & $9.12 \times 10^{3}$ & $6.11 \times 10^{3}-1.67 \times 10^{4}$ & $1 / 14(7 \%)$ \\
Changing area & $16 / 131(12 \%)$ & $7-19 \%$ & $2.83 \times 10^{4}$ & $3.01 \times 10^{4}$ & $1.41 \times 10^{4}$ & $8.36 \times 10^{3}-3.96 \times 10^{4}$ & $1 / 8(13 \%)$ \\
\hline
\end{tabular}

${ }^{a}$ Differences in the percentage of PCR-positive results were significant $(P<0.05$, Cochran-Mantel-Haenszel test) for the following pairs: Saliva compared to every other source; Spoon and cheek compared to urine, hands and changing area. ${ }^{b}$ Median viral loads were significantly different $(P<0.05$, Wilcoxon rank-sum test) for the following pairs: Saliva, spoon, cheek, washcloth and urine compared to hands and changing area 


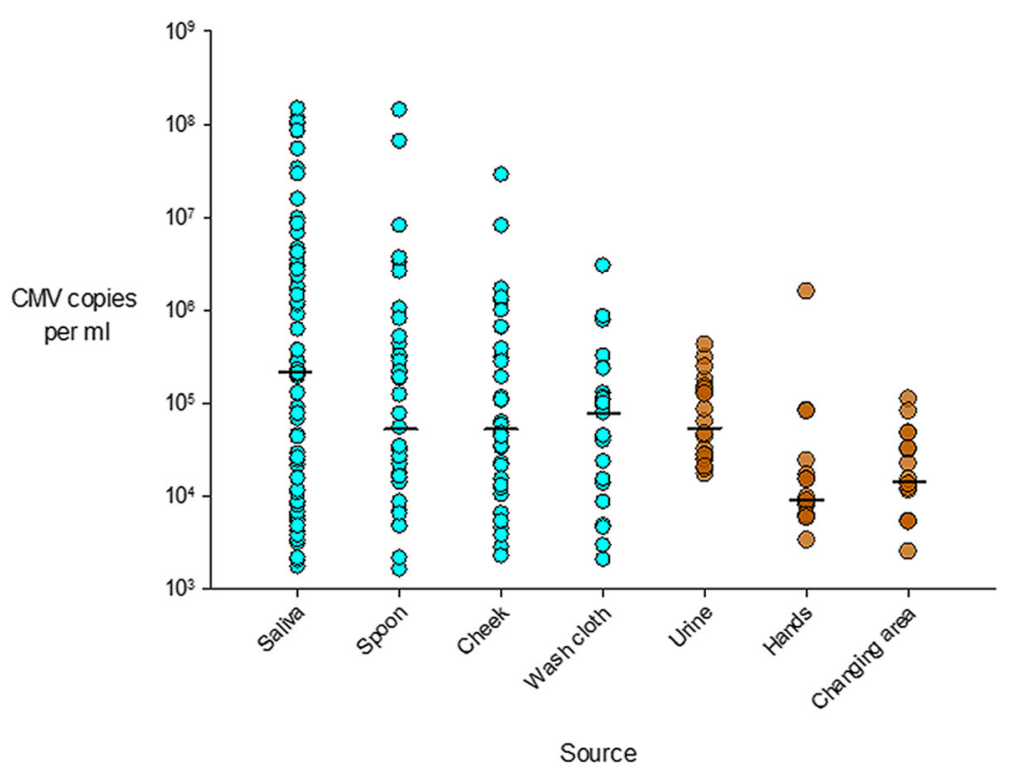

Fig. 3 Viral load range for each sample type, horizontal lines represent median viral load values. Blue color is for saliva and its contact surfaces, yellow is for urine and its contact surfaces

household members were unlikely sources of surface CMV; none of the enrolled children had siblings under 3 years of age, and adults do not often shed CMV beyond primary infection [5]. Moreover CMV seroprevalence was nearly the same for the mothers of shedders (91\%) and non-shedders (92\%).

Unique aspects of our study include the focus on surfaces in homes where there are few potential sources of $\mathrm{CMV}$, measurement of wild-type virus, and known CMV sero-status of children. Several studies since the 1980's have documented high rates of CMV shedding and transmission showing that young children are a main source of CMV transmission, and peak rates of shedding occur at 1-2 years of age $[5,17-21]$. The limited number of studies that examined environmental CMV tested surfaces inoculated with laboratory strains of CMV $[22,23]$, or were conducted in hospital nurseries with multiple potential sources of CMV that detected viable

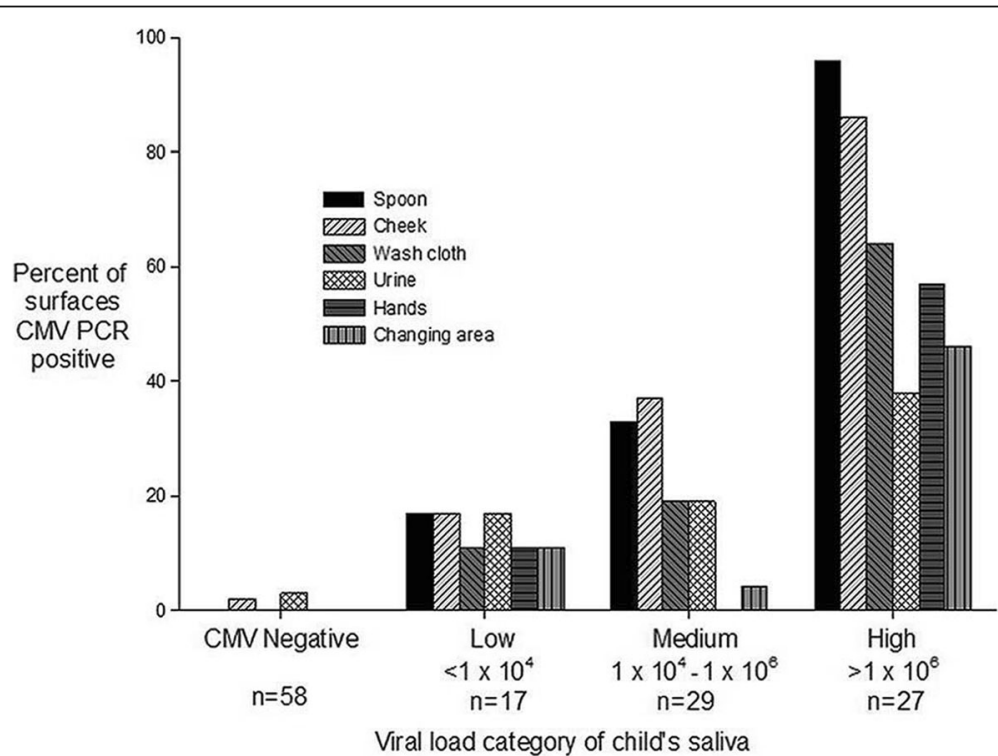

Fig. 4 CMV PCR-positivity (\%) of the six specimen types that are categorized according to the CMV viral load (low, medium, high) of the saliva from the child living in the home from which the specimens were collected. $N=$ the total number of saliva specimens collected per category 
Table 2 Association between PCR viral load and viral culture positivity

\begin{tabular}{ll}
\hline CMV Viral Load Category & Culture Positive/Total Cultures \\
\hline$<1 \times 10^{4}$ copies $/ \mathrm{mL}$ & $7 / 38(18 \%)$ \\
$1 \times 10^{4}-1 \times 10^{6}$ copies $/ \mathrm{mL}$ & $31 / 57(54 \%)$ \\
$>1 \times 10^{6}$ copies $/ \mathrm{mL}$ & $24 / 33(73 \%)$ \\
\hline
\end{tabular}

Test for linear trend for percent positive $p<0.001$

virus on medical equipment [24] or found negligible amounts of CMV on hospital surfaces [25]. One study conducted in a daycare center reported that $4 \%$ of surfaces were CMV positive, however, there was no description of surfaces tested or determination of the children's CMV serostatus [7].

Another useful result of our study is demonstration of the effective use of 903 filter paper to collect and test urine for CMV. The U.S. newborn screening program collects blood on 903 filter paper from a heel stick from virtually all infants. Blood spots are then used to screen for a wide range of birth defects. Our laboratory has previously used newborn blood spots to test for CMV [14], and in the current study we successfully used the same diagnostic methods for urine on filter paper as used for blood spots Other studies have successfully collected child urine on filter paper for CMV testing [12, 13] though not using the same diagnostic methods as used for blood spots. If universal screening for CMV were to be considered, urine collected and dried on 903 filter paper could potentially be processed similarly to DBS by the highly efficient and cost-effective U.S. newborn screening infrastructure. Limitations of our study included the relatively small sample size of 36 children and not testing the fluids of adult household members for possible CMV shedding.

Several studies to date indicate prevention education can reduce CMV infection [26-28]. Our study adds to the growing body of evidence that saliva may be the main vehicle for CMV transmission more than urine and provides evidence that objects with the child's saliva such as eating utensils can have high viral loads and viable virus that may contribute to transmission.

\section{Conclusions}

The main source for CMV on surfaces in homes was young children living in the home. Surfaces associated with saliva had higher CMV viral loads and more viable virus than surfaces associated urine, therefore saliva is likely more important vehicle for transmission than urine. Better understanding of the specific routes of transmission can lead to prevention messages that are more evidence-based and effective.

\begin{abstract}
Abbreviations
CMV: Cytomegalovirus; DBS: Dried blood spots; gB: Glycoprotein B;

NBS: Newborn screening; PBS: Phosphate buffered saline; PCR: Polymerase chain reaction; VTM: Viral transport medium
\end{abstract}

\section{Acknowledgements}

The findings and conclusions in this report are those of the authors and do not necessarily represent the official position of the Centers for Disease Control and Prevention.

\section{Funding}

This study was funded solely by the CDC.

\section{Availability of data and materials}

The datasets used and/or analysed during the current study are available from the corresponding author on reasonable request.

\section{Authors' contributions}

All authors have read and approved the manuscript. MMA contributed to specimen management, diagnostic testing and manuscript preparation. JDS contributed to study design and coordinated the schedule for home visits. WH contributed to specimen collection and diagnostic testing. PG contributed to specimen collection and diagnostic testing. DSS contributed to data analysis and figure design. MJC contributed to study design and data analysis. SCD contributed to study design, data analysis and manuscript preparation. All authors read and approved the final manuscript.

\section{Authors' information}

All authors are from the Centers for Disease Control and Prevention (CDC), 1600 Clifton Road NE, Atlanta, GA 30329 (except J. Stowell who recently moved to Emory University but all of her contributions to this work were during her time at $(D C)$.

\section{Ethics approval and consent to participate}

Ethics approval was obtained from the Centers for Disease Control and Prevention Institutional Review Board B; protocol \# 6073.0. Written consent was obtained from all parents or guardians of the children who participated in the study.

\section{Consent for publication}

Not Applicable.

\section{Competing interests}

The authors declare that they have no competing interests.

\section{Publisher's Note}

Springer Nature remains neutral with regard to jurisdictional claims in published maps and institutional affiliations.

\section{Author details}

${ }^{1}$ Centers for Disease Control and Prevention (CDC), 1600 Clifton Road NE, Atlanta, GA 30329, USA. Emory University, Atlanta, USA.

Received: 8 February 2018 Accepted: 7 August 2018 Published online: 13 August 2018

\section{References}

1. Adler SP. Cytomegalovirus transmission and child day care. AdvPediatrlnfectDis. 1992;7:109-22.

2. Ross SA, Arora N, Novak Z, Fowler KB, Britt WJ, Boppana SB. Cytomegalovirus reinfections in healthy seroimmune women. J Infect Dis. 2010;201(3):386-9.

3. Marshall BC, Adler SP. The frequency of pregnancy and exposure to cytomegalovirus infections among women with a young child in day care. Am J Obstet Gynecol. 2009;200(2):163. e161-163.e165

4. Grosjean J, Trapes L, Hantz S, Mengelle C, Virey B, Undreiner F, Messager V, Denis F, Marin B, Alain S. Human cytomegalovirus quantification in toddlers saliva from day care centers and emergency unit: a feasibility study. J Clin Virol. 2014;61(3):371-7. 
5. Cannon MJ, Hyde TB, Schmid DS. Review of cytomegalovirus shedding in bodily fluids and relevance to congenital cytomegalovirus infection. Rev Med Virol. 2011;21(4):240-55.

6. Noyola DE, Valdez-López BH, Hernández-Salinas AE, Santos-Díaz MA, NoyolaFrías MA, Reyes-Macías JF, Martínez-Martínez LG. Cytomegalovirus excretion in children attending day-care centers. Arch Med Res. 2005;36(5):590-3.

7. Hutto C, Little EA, Ricks R, Lee JD, Pass RF. Isolation of cytomegalovirus from toys and hands in a day care center. JlnfectDis. 1986;154(3):527-30.

8. Murph JR, Bale JF, Murray JC, Stinski MF, Perlman S. Cytomegalovirus transmission in a Midwest day care center: possible relationship to child care practices. J Pediatr. 1986;109:35-9.

9. Fowler KB, Pass RF. Risk factors for congenital cytomegalovirus infection in the offspring of young women: exposure to young children and recent onset of sexual activity. Pediatrics. 2006;1 18(2):e286-92.

10. Hyde TB, Schmid DS, Cannon MJ. Cytomegalovirus seroconversion rates and risk factors: implications for congenital CMV. Rev Med Virol. 2010;20(5):311-26.

11. Stowell JD, Mask K, Amin M, Clark R, Levis D, Hendley W, Lanzieri TM, Dollard SC, Cannon MJ. Cross-sectional study of cytomegalovirus shedding and immunological markers among seropositive children and their mothers. BMC Infect Dis. 2014;14(1):1-11.

12. Yamamoto AY, Mussi-Pinhata MM, Pinto PC, Figueiredo LT, Jorge SM. Usefulness of blood and urine samples collected on filter paper in detecting cytomegalovirus by the polymerase chain reaction technique. J Virol Methods. 2001;97(1-2):159-64.

13. Nozawa N, Koyano S, Yamamoto Y, Inami Y, Kurane I, Inoue N. Real-time PCR assay using specimens on filter disks as a template for detection of 'cytomegalovirus in urine. J Clin Microbiol. 2007:45(4):1305-7.

14. Kharrazi M, Hyde T, Young S, Amin MM, Cannon MJ, Dollard SC. Use of screening dried blood spots for estimation of prevalence, risk factors, and birth outcomes of congenital cytomegalovirus infection. J Pediatr. 2010; 157(2):191-7.

15. Boppana SB, Fowler KB, Pass RF, Rivera LB, Bradford RD, Lakeman FD, Britt WJ. Congenital cytomegalovirus infection: association between virus burden in infancy and hearing loss. JPediatr. 2005;146(6):817-23.

16. Cannon MJ. Repeated measures study of weekly and daily cytomegalovirus shedding patterns in saliva and urine of healthy cytomegalovirusseropositive children. BMC Infect Dis. 2014;14:569-79.

17. Picone O, Vauloup-Fellous C, Cordier AG, Chatelet IP, Senat MV, Frydman R, Grangeot-Keros L. A 2-year study on cytomegalovirus infection during pregnancy in a French hospital. BJOG. 2009;116:818-23.

18. Adler SP, Finney JW, Manganello AM, Best AM. Prevention of child-tomother transmission of cytomegalovirus by changing behaviors: a randomized controlled trial. Pediatr Infect Dis J. 1996;15(3):240-6.

19. Cannon MJ, Davis KF. Washing our hands of the congenital cytomegalovirus disease epidemic. BMC Public Health. 2005;5:70.

20. Pass RF, Hutto SC, Reynolds DW, Polhill RB. Increased frequency of cytomegalovirus infection in children in group day care. Pediatrics. 1984; 74(1):121-6.

21. Adler SP. The molecular epidemiology of cytomegalovirus transmission among children attending a day care center. JinfectDis. 1985;152(4):760-8.

22. Stowell JD, Forlin-Passoni D, Din E, Radford K, Brown D, White A, Bate SL, Dollard SC, Bialek SR, Cannon MJ, et al. Cytomegalovirus survival on common environmental surfaces: opportunities for viral transmission. J Infect Dis. 2012;205(2):211-4.

23. Schupfer PC, Murph JR, Bale JF Jr. Survival of cytomegalovirus in paper diapers and saliva. Pediatr Infect Dis. 1986;5(6):677-9.

24. Faix RG. Survival of cytomegalovirus on environmental surfaces. J Pediatr. 1985;106(4):649-52.

25. Demmler GJ, Yow MD, Spector SA, Reis SG, Brady MT, Anderson DC, Taber $\mathrm{LH}$. Nosocomial cytomegalovirus infections within two hospitals caring for infants and children. JInfectDis. 1987;156(1):9-16.

26. Adler SP, Finney JW, Manganello AM, Best AM. Prevention of child-tomother transmission of cytomegalovirus among pregnant women. JPediatr. 2004; 145(4):485-91.

27. Vauloup-Fellous C, Picone O, Cordier AG, Parent-du-Chatelet I, Senat MV, Frydman R, Grangeot-Keros L. Does hygiene counseling have an impact on the rate of CMV primary infection during pregnancy? Results of a 3-year prospective study in a French hospital. J Clin Virol. 2009;46(Suppl 4):S49-53.

28. Revello MG, Tibaldi C, Masuelli G, Frisina V, Sacchi A, Furione M, Arossa A, Spinillo A, Klersy C, Ceccarelli M, et al. Prevention of primary cytomegalovirus infection in pregnancy. EBioMedicine. 2015;2(9):1205-10.

Ready to submit your research? Choose BMC and benefit from:

- fast, convenient online submission

- thorough peer review by experienced researchers in your field

- rapid publication on acceptance

- support for research data, including large and complex data types

- gold Open Access which fosters wider collaboration and increased citations

- maximum visibility for your research: over $100 \mathrm{M}$ website views per year

At BMC, research is always in progress.

Learn more biomedcentral.com/submissions 